\title{
DEVELOPMENT AND RESEARCH IN VACUUM TECHNIQUES
}

\begin{abstract}
HE profound importance of high vacuum in research during the past decade or two is generally realized, but not, perhaps, the extent to which laboratory discoveries have led to important and increasing applications in industry since the Second World War. Without, for example, modern mothods of pumping and leak detection for very large-scale projects, the utilization of atomic energy and all its implications would be impossible. W. Edwards and Co. have, almost since the inception of the company thirty-five years ago, specialized in vacuum techniques and therefore have been closely associated with its remarkable development, progressing during this time from a one-man business to the present organization consisting of some five hundred people.
\end{abstract}

At a luncheon held on March 5 to mark the opening of the Company's new factory at Crawley New Town, Sir Ben Lockspeiser, Secretary of the Department of Scientific and Industrial Research, referred to the vital necessity of research for the future of Britain, and said: "Not so long ago it was customary to speak of industry supporting science, but a research director of a famous American firm has rightly pointed out that, in these days, it is science which supports industry". After reviewing the important role of high vacuum, he pointed out that great industrial innovations now demand large sums for development and copital investment, which can only be met by large organizations; but, he said : "There is a vital and distinctive place for the specialist firm, which mokes itself highly proficient in its own field and performs thereby an invaluable service for many industries, and often for research laboratories also. Messrs. W. Edwards and Co. is an excellent example of such a specialist firm, occupying a unique position and serving both industry in the newest technology and science in its most advanced technique".

Referring to the early days of the company, Sir Ben said : "In its great services to science, Messrs. W. Edwards and Co. is handsomely repaying an old debt, for I believe I am right in saying that about 1924 Dr. G. W. C. Kaye, who was head of the Physics Division of the National Physical Laboratory at the time, invented a new type of vacuum pump and approached Mr. Edwards, the present managing director of the Company, with a view to getting it manufactured. The Company began in this way by manufacturing Dr. Kaye's pump. The Company turned to the research laboratory for a good start in life, and it now makes a valuable contribution to keeping research alive".

Sir Ben urged that any research organization should include some people (there never could be very many) free to take long views and concern themselves with the fundamentals, so that the capital of scientific thought on a subject should not dry up-an event as serious as a failure of capital in finance-and concluded by saying: "The advance of science depends on new ideas, and your industry is -and always will be-in need of them. Cherish, therefore, the goose that lays the golden egg".

A tour of the new factory shows to what extent the firm has realized the value of research so stressed by Sir Ben, for a considerable floor area of the light and airy modern factory is devoted to research. The laboratories have been kept contiguous to one another, for work in one section greatly influences work in other sections. Thus workers on pumping problems have developed a gas-ballast rotary vacuum pump to deal with the contamination difficulties arising in the vacuum coating section, where the continuous coating of roll material has been developed, and in the freeze-drying section, where large volumes of water vapour must be handled. Vacuum metallurgy developments have also profited by allied problems arising in vacuum coating large areas, where significant quantities of metal must be evaporated. Not only is exploratory work undertaken to devise new and more efficient apparatus and keep the firm abreast of the latest developments, but also considerable investigation is carried out to develop plant and techniques to meet customers' applications - often work which may appear to have no connexion with high vacuum, for example, investigation into lacquers as an important complementary to the deposition of thin metallic films in vacuum.

No part of the floor area of the research sections is more than $20 \mathrm{ft}$. from a bus-bar system with plug-in fuse boxes for electricity, or from gas, coolingwater and compressed air supplies. Writing and discussion rooms are provided for each research section, as past experience of the firm has shown that the laboratory itself is not the most suitable place for the preparation of reports and reasoned discussion.

It is the firm's policy to encourage the use of its research staff in customer relations, and the Sales Department is organized accordingly. Not only is this important because of the new fields with which high vacuum is concerned, but also it keeps the sales organization closely informed of developments in the laboratory and at the same time maintains the interest of the research workers in the end-products of their work, stimulates their ideas and ensures a recognition of practicability.

The staffing of a research department in a new and specialized branch of applied science presents difficulties; taking a long-term view, research apprenticeships have been instituted. The apprentice serves the bulk of his time in the various sections of the laboratory, with training in the works and drawing office, and with one day each week to further formal education, for a period of five years. Training of research apprentices is not the only educational function of the firm's Research Department, as it is the focal point of experience for postgraduate students, who come from all over the world for summer vacation work.

The Company's reference library is of a very high standard in view of the importance which is attached to the abstraction and internal circulation of information on articles published throughout the world on high vacuum and allied subjects. This led to vacuum workers outside the firm appreciating the value of such a service, with frequent requests for copies of the abstracts, and in turn became the genesis of the periodical Vacuum, which was started four years ago as a journal, independent of the 
parent Company, to publish abstracts, together with authoritative articles on its subject.

Mr. F. D. Edwards, replying to Sir Ben Lockspeiser, referred to the indebtedness of the Company, in its early days, when extensive advertising was quite beyond it, to the Physical Society's annual exhibition, where it was able to display its products to the scientific world through this unique medium. He went on to say that it is interesting to consider the many large organizations which have evolved from one-man enterprises established in the days of low taxation, when profits could be ploughed back to build up the firm's working capital. With modern taxation, it is virtually impossible for a young enterprise to grow without outside capital, and hence, he said: "Small enterprises will have to rely upon private funds for expansion, and therefore it is my hope that financiers and industrialists will take courage in both hands and be prepared to risk financial support to small enterprises until they reach such size that they can properly be handled by finance institutions. If some such action is not taken, many promising ideas will perish from lack of funds and possible world markets be lost to Britain".

\section{ERGONOMICS RESEARCH SOCIETY}

\section{FOURTH ANNUAL CONFERENCE}

$\mathrm{T}$

HE fourth annual conference of the Ergonomics

Research Society was held during April 5-7 at Ashorne Hill, near Leamington. Following the precedent of earlier years, the papers were planned around one main theme, on this occasion "The Scientific Study of Human Work in Industry". Sir George Barnett, H.M. Chief Inspector of Factories, opened the conference, reminding his hearers that the administration of the Factories Acts brings him and his staff into daily contact with the matters covered by this new term 'ergonomics'. Quite apart from hazards of accident and industrial disease, the Acts deal with heating, ventilation, lighting and seating ; inspectors are constantly reminded of the physiologicel and psychological importance of these, and of the need for further progress in such directions as the design of machinery. He suggested that one of the msin problems of the future would be the adaptation of methods of work to a population including an increasing number of older people, and, very reasonably, he pointed out that research results on this or any other problem are more likely to be used if reported in terms comprehensible to the interested loyman.

The first paper, given by O. G. Edholm, was a contribution to understanding by the layman- of physiological methods of measuring work. Admitting the impossibility of a complete exposition, Dr. Edholm nevertheless outlined the various effects of activity on the human body in a way which made subsequent papers far more useful to the non-physiologist. He dealt with metabolism at rest and at work, giving in round figures the amounts of heat involved; his comparisons of oxygen usage were illustrated by demonstration, the subject at first sitting, and then stepping up and down. The limits of activity as set by heat loss, or cardiac capacity, or by other reasons were discussed, and the distinction was drawn between fatigue due to posture and that due to work in the mechanical sense of foot-pounds expended.
Two papers dealt with the physiological stress of heavy work in hot surroundings, the first by J. S. Weiner and A. R. Lind, and the second by H. S. Belding and T. F. Hatch. Both were primarily concerned with the same problem-that of setting limits to environmentel conditions which, while expressed in physical terms readily measurable by engineers, would safeguard the human being working in them. Weiner and Lind discussed the various permissible limits that had been proposed in coal mining, in particular examining the discrepancy between the figures put forward by Linsel in Germany in 1949 and those deduced from a variety of other sources, which, while agreeing among themselves, suggest that Linsel's limit is somewhat low. The second paper (which was read by Prof. Belding alone) accepted the challenge to set physiological limits in a simple and easily measured way; in extremely hot jobs in the glass and metal industries, it has been found practically effective to calculate the total heat input and to balance this against sweat-rate. Input was calculable from radiant tempersture, air temperature and movement, and metabolism estimated from the work done; a maximum sweatrate of $1 \mathrm{l} . / \mathrm{hr}$. for a spell of 6-8 hr. for "very fit, acclimatized men" was postulated. In hot and moist conditions, the limit would be the rate of evaporation rather than the rate of sweating. Both these papers dealt with working conditions far above the accepted range of comfort; the paper by D. E. Hickish on the thermal comfort of workers in light industries in summer dealt not merely with physical and physiological data, but also with the subjects' views expressed on a rating scale. Discussion of the physiological limits suggested that work should preferably be well within them; mention of accident-rates in mining illustrated this, with the question "At what point does the man become irritable and liable to be careless ?". The psychologists have much work ahead of them in such problems.

As R. Harper put it, his paper on the study of craftsmanship in dairying was concerned with the cross-links between the physical problem of measuring the properties of deformable material and the psychological problems of describing and codifying the experiences gained from handling it. The particular material described was cheese; but apparently similar problems exist in connexion with wool and other substances of natural origin. Cheese graders have long used tests such as pressing with the thumb to assess the condition of cheese; the obvious course of tasting is rarely resorted to, since no pelate could stand up to the large number of cheeses. The research was not concerned merely with relating subjective judgments to instrument readings ; a major difficulty was that of relating either of these to the ultimate criterion of the goodness of the cheese.

Sven Forssman described a study of workers in underground factories in Sweden which demonstrated the effect of psychological factors very clearly. Workers in three underground factories had complained of fatigue, eye-strain and the like; in the study they were compared with a similar population working above ground. There appeared to be little difference from a medical point of view between the two groups, and only in some places were conditions of lighting worse for the underground workers. But it was concluded that, other things being equal, the psychological climate among the underground workers was more sensitive, and any shortcomings in human 